\title{
Eduportfolio: a tool for second language teachers
}

\section{Eduportfolio: uma ferramenta para professores de lingua estrangeira}

\section{Thierry Karsenti ${ }^{[a]}$, Simon Collin ${ }^{[b]}$}

[a] Ph.D., Canada Research Chair em Tecnologia da Informação e Comunicação (TIC) em Educação, professor da Université de Montréal, Montréal; Canadá, e-mail: thierry.karsenti@umontreal.ca

${ }^{[b]}$ M.Ed., coordenador de pesquisa no Centre de Recherche Interuniversitaire sur la Formation et la Profession Enseignante (CRIFPE), Université de Montréal, Montréal - Canadá, e-mail: simon.collin@umontreal.ca

\begin{abstract}
Originally used in artistic circles, the portfolio has gained considerable ground in the education field, where it serves a multitude of functions, both academic and professional. It is also a rapidly evolving tool, notably due to advances in Web 2.0 technology that have opened the way to new pedagogical potentials. The portfolio is also prominent in second-language teaching and learning programs, as witnessed by the European Language Portfolio (ELP), which was developed and piloted by the Council of Europe and is used as a support tool in line with the
\end{abstract}


Common European Framework of Reference for Languages (CEFR). In this context, we present Eduportfolio, a flexible electronic portfolio that can be adapted to a variety of educational contexts, including second language (L2) education. We draw a portrait of the portfolio in education, including the advantages of the electronic version. We then present Eduportfolio along with some empirical results to illustrate eportfolio use in French second language (FSL) teaching and learning.

Keywords: Eportfolio. FSL teaching and learning. Web 2.0.

\section{Resumo}

Originalmente utilizado no mundo artístico, o portfólio tem ganhado considerável repercussão no campo educacional, o qual tem servido a uma diversidade de funções, tanto acadêmicas quanto profissionais. Rapidamente, ele se torna também uma envolvente ferramenta graças aos avanços da tecnologia Web 2.0, que tem aberto caminho para novos desenvolvimentos pedagógicos. O portfólio se destaca também nos programas de ensino e aprendizagem de uma lingua estrangeira, como é testemunhado pelo Portfólio de Linguagem Europeu (European Language Portfolio-ELP), que foi desenvolvido e conduzido pelo Conselho Europeu para ser usado como uma ferramenta de suporte em linha, dentro do âmbito do Quadro Comum Europeu de Referência para a Linguagem (Common European Framework of Reference for Languages - CEF R). Nesse contexto, apresentamos o Eduportfólio, um portfólio eletrônico e flexível, que pode ser adaptado a uma variedade de contextos educacionais, incluindo o ensino da língua estrangeira (L2). Inicialmente, esboçamos um retrato do uso do portfólio na educação, incluindo as vantagens da versão eletrônica dessa ferramenta. Na sequência, apresentamos o Eduportfólio, por meio de alguns resultados empíricos que ilustram o uso dessa ferramenta para o ensino e aprendizagem da lingua francesa como segunda lingua (FSL).

Palavras-chave: Eportfólio. Ensino e aprendizagem de língua estrangeira. Web 2.0. 


\section{The portfolio in education}

This section presents a general overview of the portfolio, including its functions in education, and more specifically, its pedagogical use in L2 classes.

\section{Functions of the portfolio in education}

The portfolio originated in artistic circles, the idea being that artists could get their works exhibited by presenting a set of representative examples. It was first applied to education in the early 1980s by P. Elbow and P. Belanoff (State University of New York, Stony Brook) as an alternative to standardized tests (BRÄUER, 1999). Since then the portfolio has been expanded to a multitude of functions. The main ones are presented below:

a) exposure function: the educational portfolio showcases students' learning and progress with examples of their schoolwork (EYSSAUTIER-BAVAY, 2004). Its progressive nature allows insight into both learning processes and outcomes (BELANOFF; DICKINSON, 1991; GOUPIL; PETIT; PALLASCIO, 1998), as it represents the student's learning path. This function can also be exploited professionally: job candidates can show potential employers how their skills have developed (BUCHETON, 2003);

b) assessment function: the portfolio is often used as a complementary assessment tool (GRESSO;LOMICKA, 1999). Because it provides access to both process and outcome, it can be used for ongoing formative as well as summative assessments. It also provides teachers with an additional source of information with which to confirm or moderate their judgement. Furthermore, the portfolio can be used as a self-assessment tool to foster learner autonomy and responsibility for the learning process (LITTLE, 2005), accompanied by a self-assessment grid;

c) reflective function: the above-mentioned self-assessment function is part of the reflective function, whereby students adopt a critical attitude toward their learning (GRESSO; LOMIKCA, 1999). Aside from the use of predetermined self-assessment grids, reflection on the learning process can be fostered through frequent writing 
of "feedback" reports (e.g., "What I have learned," "My strengths and weaknesses," "If I could do it over") (EYSSAUTIER-BAVAY, 2004). Moreover, students must exercise their reflective capacity to select the most representative examples of their learning. The portfolio therefore departs from an archival record in that students continuously input relevant and representative content;

d) social function: the portfolio also provides a social function when it acts as a mediation tool between learners, teachers, and parents. Importantly, it enables parents to gain a better understanding of their child's learning path, which may encourage them to get more involved in the process. Note that the paper version does not provide this social function, which emerged with the technological advance of the electronic portfolio, and is therefore specific to the eportfolio.

\section{Pedagogical use of the portfolio in L2 class}

The above-presented functions demonstrate that the portfolio is a tool with strong potential to support learning in any subject, and particularly L2. It allows students to review their progress in second-language learning. Moreover, this can be done in the second language, through writing, which particularly helps students reflect on their learning (MINUTH, 1999). Thus, students can reflect on their advancement in L2 while working in that linguistic mode.

There are many ways to organize portfolio content. For example, the European Language Portfolio (for a more detailed description of the ELP, see Council of Europe (2004) and Little (2010) comprises three parts: the Language Passport, which provides an overview of the individual's proficiency in different languages at a given point in time in terms of the common reference levels; the Language Biography, which provides a multilingual perspective on the learner's experience with different languages; and the Dossier, where the learner documents examples of personal works to illustrate the competencies listed in the Language Passport and Language Biography. Note that these three parts can be combined in various forms and used at various times throughout the L2 program.

Other content organizations are equally possible. Among others, it could be advantageous to arrange the portfolio according to assessments 
of second-language notions. For example, following the competencybased approach used in Canada, a student's portfolio could be organized to reflect the different competencies specified in the L2 program. Students could then select accomplishments that are directly related to the required competencies. This would also make it easier for teachers to assess the different competencies.

\section{Presentation of Eduportfolio}

This section deals with the more technical aspects. The advantages of the eportfolio over the paper portfolio are presented, and the specific functions of Eduportfolio are described.

\section{Advantages of the eportfolio}

The electronic portfolio has a number of distinct advantages over the paper portfolio, as outlined below:

a) greater social function: because it usually includes a "comments" function, the eportfolio enables greater communication between students and other parties in the education process (teachers, parents, other students), which provides opportunities for feedback. This increases the social function of the portfolio and adds the potential to set up learning communities. The cyberportfolios of the Institut St-Joseph are an excellent example of the role that the eportfolio can play in a learning community. Similarly, Eduportfolio has several network functions that support this type of collaboration;

b) flexibility of content organization: the electronic portfolio also allows flexible content organization, which in turn fosters portfolio evolution. In other words, this flexibility means that learners can adapt their portfolios to their learning path, adding new sections and changing old ones as they go along. In this respect, paper portfolios such as the European Language Portfolio are limited in that they require all learners to adhere to the same content organization, 
and for the entire duration of their L2 program. However, it is arguable that a preschool and a secondary school student might not have the same needs in terms of content organization. The same holds true for beginner and advanced students;

c) flexibility of content: aside from flexibility of content organization, the eportfolio also provides flexibility of the content itself. For example, using a computer, one can delete, replace, cut and paste, and correct texts as desired, all without hindering the readability. This delinearization of the writing process, which is typical of word processing, Anis (1998) has a significant impact on L2 teaching and learning, because learners can review their work to their heart's content and publish a number of versions of the same text to track their progress longitudinally;

d) enormous storage capacity: the eportfolio typically has enough storage capacity to host a vast number of texts that are nonetheless simple to manage. To illustrate, Eduportfolio provides an initial 100 Mo of storage space. In contrast, a voluminous paper portfolio would be heavy, unwieldy, and possibly confusing. In this sense, the eportfolio appears to have the long-term advantage;

e) aesthetics: the eportfolio is an aesthetic tool owing to two features that paper portfolios generally lack: (1) first, it usually offers a wide choice of templates, colours, and images, for plenty of style options; and (2) as mentioned above (content flexibility), writing on a computer produces texts that are uniform and legible, for consistent readability;

f) accessibility: when the eportfolio is posted online, it provides universal access, as long there is an Internet connection. Unfortunately, this is the eportfolio's one major inconvenience: unlike the paper version, it requires technological support. In other words, the eportfolio can be used only in L2 classrooms where students have access to computers and the Internet.

\section{Functions of Eduportfolio}

Now that we have looked at the advantages of the eportfolio over the paper portfolio, we can turn to the main functions of Eduportfolio, in 
addition to those listed immediately above. Eduportfolio is a free-access, multilingual electronic portfolio that is specifically designed for educational purposes. Instead of following a predefined content organization, users can structure the content by section and subsection, adding texts and documents as desired. Because the content organization varies according to the portfolio, each Eduportfolio Home page includes a Page list and navigation buttons. This allows readers to quickly view the portfolio's contents using different and complementary functions, as shown in Figure 1.

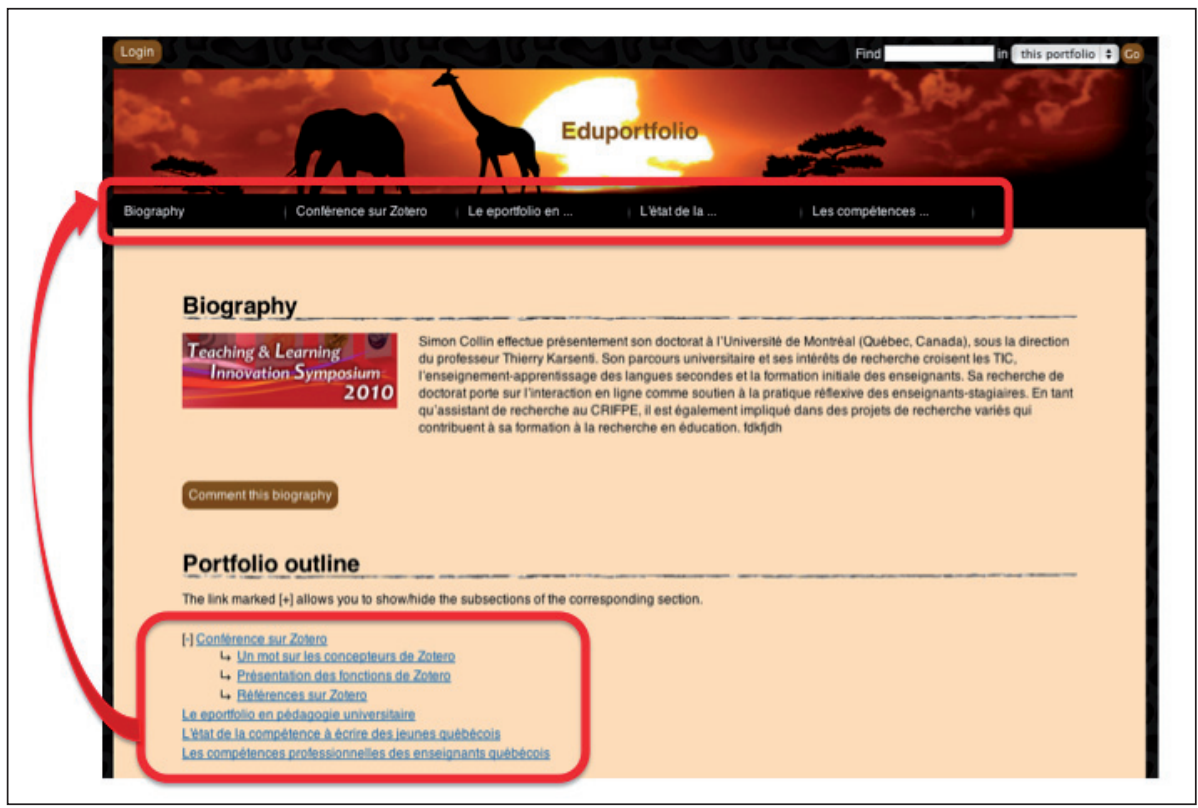

Figure 1 - Page list at Eduportfolio

To protect their identity and confidentiality, authors can block access to specific sections and subsections and require users to supply a password to view certain portfolio content. Note also that items on Eduportfolio can be published in a variety of formats (e.g., text, audio, video, PPT, image, graphics). This provides teachers and learners with a number of interesting L2 options, including written texts and oral productions using audio and video clips. Eduportfolio also has some of the most technologically advanced Web 2.0 functions: RSS feed, 
invitation function, chat system, and Twitter notification of new content. Eduportfolio offers still another advantageous feature: downloading static versions of the portfolio. A static version requires a computer to be read and printed out, but does not require Internet access. This partly redresses the previously mentioned accessibility limitation, and provides a particularly useful option for "transporting" a portfolio. Finally, apart from educational applications, Eduportfolio includes a portfolio manager so that teachers can group, manage, and access all their students' portfolios on one site, in one place.

\section{Results on the integration of Eduportfolio in initial teacher training programs}

We conclude by presenting an overview of the results of a study on the pedagogical integration of Eduportfolio by teachers-intraining at the Université de Montréal, including those in FSL programs. The study was conducted in winter 2010 (December-March) using an online questionnaire $(\mathrm{N}=403)$ and semi-directed interviews $(\mathrm{N}=8)$ of students enrolled in an initial teacher training program. Below we present the quantitative results and draw a portrait of students' perceptions towards the use of Eduportfolio in their teacher training program. We then present the qualitative results in the aim of gaining a deeper understanding of this portrait. We will limit ourselves to presenting the most relevant results on the pedagogical integration of Eduportfolio in second-language education.

First, we must stress that a consistent finding in this study (and in previous studies on other education programs) was the mandatory use of the eportfolio. Indeed, using Eduportfolio was an academic requirement for $82 \%$ of respondents (Figure 2). On the other hand, support for learning, support for reflective practice, and professional visibility functions varied widely among respondents. Thus, respondents' answers were relatively evenly distributed (30-45\% for "Strongly agreeAgree," "Neutral" and "Strongly agree-Disagree") for these three functions, which suggests rather diverse perceptions of Eduportfolio' academic and professional potential. 


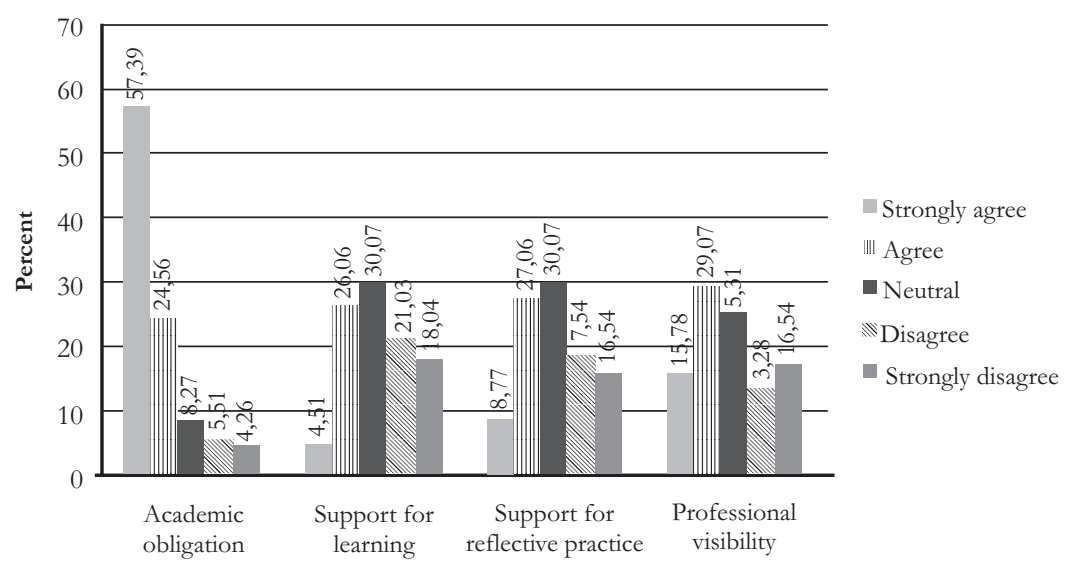

Figure 2 - Motivation to use Eduportfolio in initial teacher training

Based on these results, we hypothesize that [future teachers will experience??](or)[teachers-in-training experience] the use of Eduportfolio in very different ways, most probably due to different instructions on its use by their university professors. Another finding is that Eduportfolio was mainly perceived as an individual rather than collaborative tool (Figure 3). This indicates that Eduportfolio's collaborative potential, as mentioned, was underused.

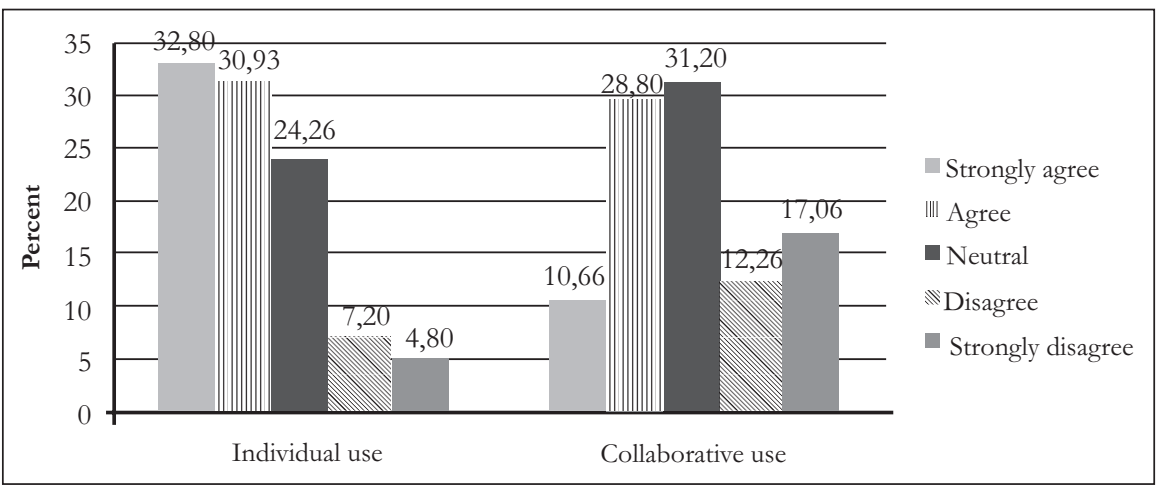

Figure 3 - Individual versus collaborative perception of Eduportfolio in initial teacher training 
We therefore hypothesize that university professors do not direct their students to exploit the full interactional and social potential of Eduportfolio. This can be viewed as an unrealized gain in certain learning situations, particularly from a social constructivist perspective.

We turn now to the conditions for the pedagogical integration of Eduportfolio. In terms of curriculum implementation, a number of conditions are required for the effective use of Eduportfolio:

a) predefined pedagogical objectives: before this tool is used in a language course, the pedagogical objectives should be determined. This step could be carried out by an education team, and should account for the school's particular context;

b) complementarity with existing toos: it is equally important to ensure that the pedagogical integration of Eduportfolio is not redundant with tools that are already in place. Otherwise learners will fail to appreciate its educational value;

c) technical and pedagogical support for teachers: because teachers play a primary role in the integration of Eduportfolio in language courses, they must be provided with the technical and pedagogical support they need to make good use of this approach.

Once Eduportfolio has been introduced into the curriculum, certain conditions are required so that learners can fully appropriate this tool:

a) pedagogical instruction for learners in the use of Eduportfolio: the eportfolio differs from other learning tools in the largely autonomous nature of the learning process. In addition to technical training in the use of Eduportfolio, it is therefore necessary to provide training in the unique way that this tool fosters learning. Moreover, this training should be provided over time (e.g., at the beginning of each session if Eduportfolio is used for several years) in order to guide learners as they familiarize themselves with the technical features and pedagogical potentials;

b) regular use and coaching in language courses: due to its unique nature, the eportfolio gives better value in language courses if it is used regularly and with coaching. It is known that learning processes such as reflection and self-regulation - which the eportfolio 
particularly targets - are generally less developed in traditional, teacher-directed language programs. Moreover, to benefit from the full potential of Eduportfolio, learners must use it regularly and with coaching. This coaching can take many forms: self-assessment sheets, peer assessment, class and group presentations, scheduled meetings with teachers, and so on.

From this brief overview of the results we gather that the pedagogical integration of Eduportfolio, like any other educational tool, is subject to conditions of the curriculum as well as pedagogical conditions as such. These conditions are important to take into consideration so that learners can fully appreciate the educational value of Eduportfolio, and consequently fully benefit from its potential in second-language learning.

\section{Conclusion}

This paper presents Eduportfolio, an L2 teaching and learning tool. We described the functions of the portfolio in education, and more particularly in L2 teaching and learning. We then presented Eduportfolio, citing the advantages of the electronic portfolio over the paper portfolio and the specific advantages of Eduportfolio. While Eduportfolio promises to provide strong support for $\mathrm{L} 2$ teaching and learning, recent advances in teaching and technology suggest that it could do even more. One possible improvement would be to expand the social function, for example by including "eportfolio friends" or by making use of the available interaction modes (asynchronous and synchronous) to encourage students to form learning communities.

\section{References}

ANIS, J. Texte et ordinateur. L'écriture réinventée? Paris/Brussels: De Boeck université, 1998.

BELANOFF, P.; DICKINSON, M. Portfolios: process and product. Portsmouth, NH: Heinemann, 1991. 
BRÄUER, G. Le Portfolio, moyen d'apprentissage et d'enseignement personnalisés. Tracer, v. 15, p. 31-46, 1999.

BUCHETON, D. Du portfolio au dossier professionnel: éléments de réflexion, 2003. Disponível em: < http://probo.free.fr/textes_amis/portfolio_bucheton. pdf $>$. Acesso em: 20 mar. 2010.

COUNCIL OF EUROPE. European language portfolio (ELP): principles and guidelines. Strasbourg: Author, 2004.

EYSSAUTIER-BAVAY, C. Le portfolio en éducation: concepts et usages. In: COLLOQUE TICE MÉDITERRANNÉE, 1., 2004, Nice, France. Proceedings... Nice, France: ISDM, 2004. p. 265-271.

GOUPIL, G., PETIT, E-L.; PALLASCIO, M-C. Le Portfolio: un pas vers une évaluation plus "authentique" orientée vers l'acquisition de compétences. Revue Québécoise de Psychologie, v. 19, n. 2, p. 167-181, 1998.

GRESSO, H.; LOMICKA, L. Le portfolio: une méthode active, constructive, réflective. Tracer, v. 15, p. 23-30, 1999.

LITTLE, D. The common european framework and the european language portfolio: involving learners and their judgments in the assessment process. Language Testing, v. 22, n. 3, p. 321-336, 2005.

LITTLE, D.; PERCLOVÁ, R. The european language portfolio: a guide for teachers and teacher trainers. Disponível em: <http://www.coe.int/T/DG4/ Portfolio/documents/ELPguide_teacherstrainers.pdf $>$. Acesso em: 20 maio 2010.

MINUTH, C. Écrire pour construire une réflexion sur les apprentissages. Tracer, v. 15, p. 11-22, 1999.

Received: 04/12/2010

Recebido: 12/04/2010

Approved: 05/25/2010

Aprovado: 25/05/2010 